Н. В. Кондрашова, А. А. Михайлова. Методы оценки социально-экономического положения малообеспеченных семей

Научная статья

УДК 330.59+364

DOI 10.18101/2304-4446-2021-1-49-61

\title{
МЕТОДЫ ОЦЕНКИ СОЦИАЛЬНО-ЭКОНОМИЧЕСКОГО ПОЛОЖЕНИЯ МАЛООБЕСПЕЧЕННЫХ СЕМЕЙ
}

\section{(C) Кондрашова Наталия Васильевна}

кандидат социологических наук, доцент prokusheva0103@mail.ru

\author{
(C) Михайлова Анастасия Александровна \\ магистр социальной работы \\ daughter_of_laos_jr@mail.ru
}

Бурятский государственный университет имени Доржи Банзарова Россия, 670000, г. Улан-Удэ, ул. Смолина, 24а

Аннотация. Существуют различные категории семей, среди них можно выделить малообеспеченные семьи, которые и являются объектом настоящего исследования. В статье обозначается тревожная тенденция к возрастанию количества малообеспеченных семей, делается попытка определить причины и факторы, оказывающие влияние на этот деструктивный общественный процесс. Появление малоимущих семей есть результат современной экономической, политической ситуации, сложившейся в стране и оказавшей влияние на ослабленные слои населения, в том числе и семьи. В современных реалиях за чертой бедности часто оказываются не только социально уязвимые категории семей (многодетные, неполные), но и семьи, относительно благополучные, которые по каким-либо причинам не смогли адаптироваться к кризисной ситуации и условиям рынка. Большинство бедных семей России - трудоспособные семьи с детьми.

Ключевые слова: бедность; благосостояние; доход; качество жизни; малообеспеченность; минимальный размер оплаты труда; потребительская корзина; прожиточный минимум; семьи с детьми; уровень жизни.

\section{Для цитирования}

Кондрашова Н. В., Михайлова А. А. Методы оценки социально-экономического положения малообеспеченных семей // Вестник Бурятского государственного университета. Экономика и менеджмент. 2021. № 1. С. 49-61.

В современной науке и практике существует множество методов и критериев оценки и измерения бедности, что объясняется различными методологическими подходами к ее определению.

Согласно действующему Федеральному закону от 24 октября 1997 г. № 134Ф3 «О прожиточном минимуме в Российской Федерации» ${ }^{1}$, семья считается ма-

\footnotetext{
${ }^{1}$ О прожиточном минимуме в Российской Федерации» (с изменениями и дополнениями): федеральный закон от 24 октября 1997 г. № 134-Ф3 «[Электронный ресурс]. URL: http://www.consultant.ru/document/cons_doc_LAW_90091/f4a8b1dfb9dd094a8e814ac8d398c 59ee490e2e4/ (дата обращения: 13.01.2021). Текст : электронный.
} 
лообеспеченной, если среднедушевой доход каждого ее члена находится ниже величины прожиточного минимума, установленного в соответствующем субъекте РФ по месту проживания. По данным Федеральной службы государственной статистики Российской Федерации в Республике Бурятия, величина прожиточного минимума в среднем на душу населения выросла с 7214 р. в 2013 г. до 12341 р. в 2020 г. на душу населения [4]. По этим данным явно видна устойчивая тенденция роста величины прожиточного минимума в Республике Бурятия, разница размера прожиточного минимума составляет 5127 руб. Соответственно, увеличение размера прожиточного минимума влечет за собой увеличение количества малообеспеченных семей, а следовательно, обращения за мерами государственной социальной поддержки. По данным социального паспорта Министерства социальной защиты населения Республики Бурятия на 1 марта 2018 г., число семей, получающих такую социальную помощь от государства, достигло 62978. Ранее таких семей было зарегистрировано 47 360, за этот период количество малообеспеченных семей увеличилось на 15 618. В зависимости от роста числа малообеспеченных семей увеличивается нагрузка на государственный и региональный бюджет, а следовательно, и на органы государственной власти.

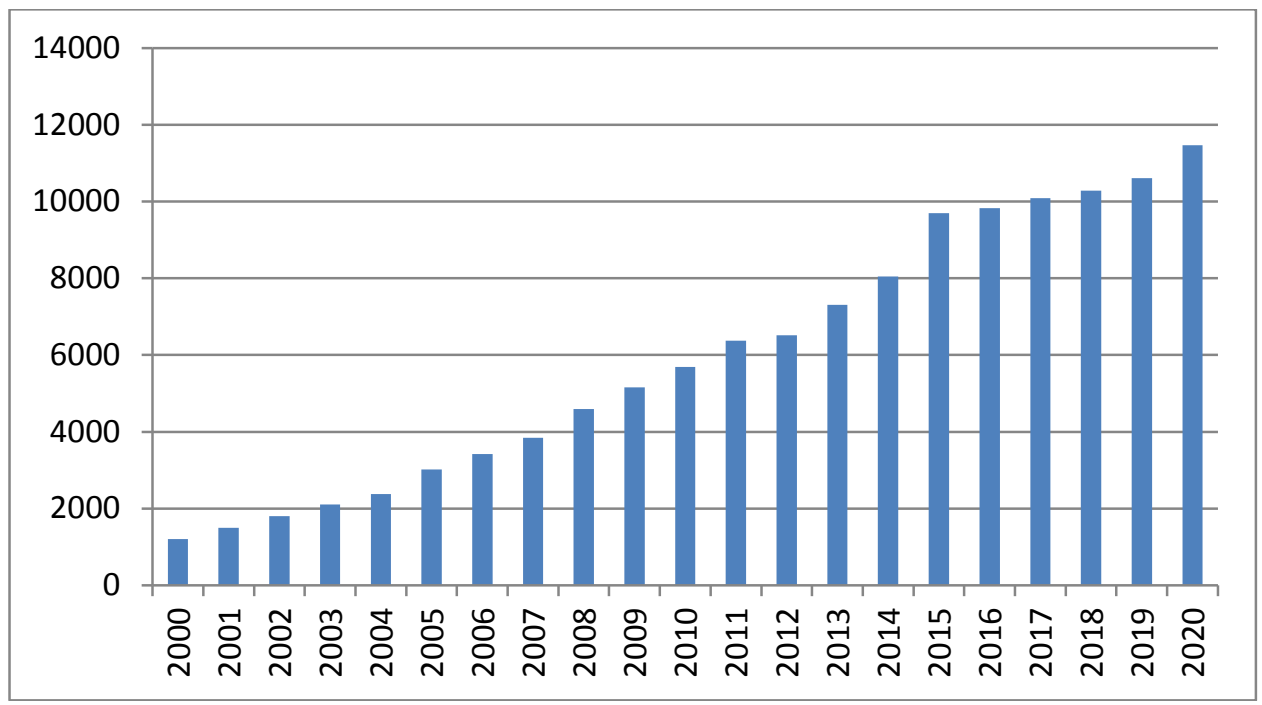

Рис. 1. Величина прожиточного минимума по годам (2000-2020 гг.)

Число россиян с доходом ниже величины прожиточного минимума увеличилось во втором квартале 2020 г. на 1,3 млн по отношению к аналогичному периоду 2019 г. и составило 19,9 млн (13,5\% населения страны). По данным Росстата, во втором квартале 2019 г. число бедных россиян составляло 18,6 млн (12,7\% населения). При этом по итогам первого полугодия 2020 г. численность бедных снизилась по отношению к аналогичному периоду 2019 г. с 19,8 млн (13,5\%) в 2019 г. до 19,4 млн (13,2\%) в 2020 г. По итогам второго квартала 2020 г. величина прожиточного минимума в РФ на душу населения в среднем по РФ составила 12 тыс. 392 р. для трудоспособного населения, 9 тыс. 422 р. для пенсионеров и 11 тыс. 423 р. для детей [7]. 
Н. В. Кондрашова, А. А. Михайлова. Методы оценки социально-экономического положения малообеспеченных семей

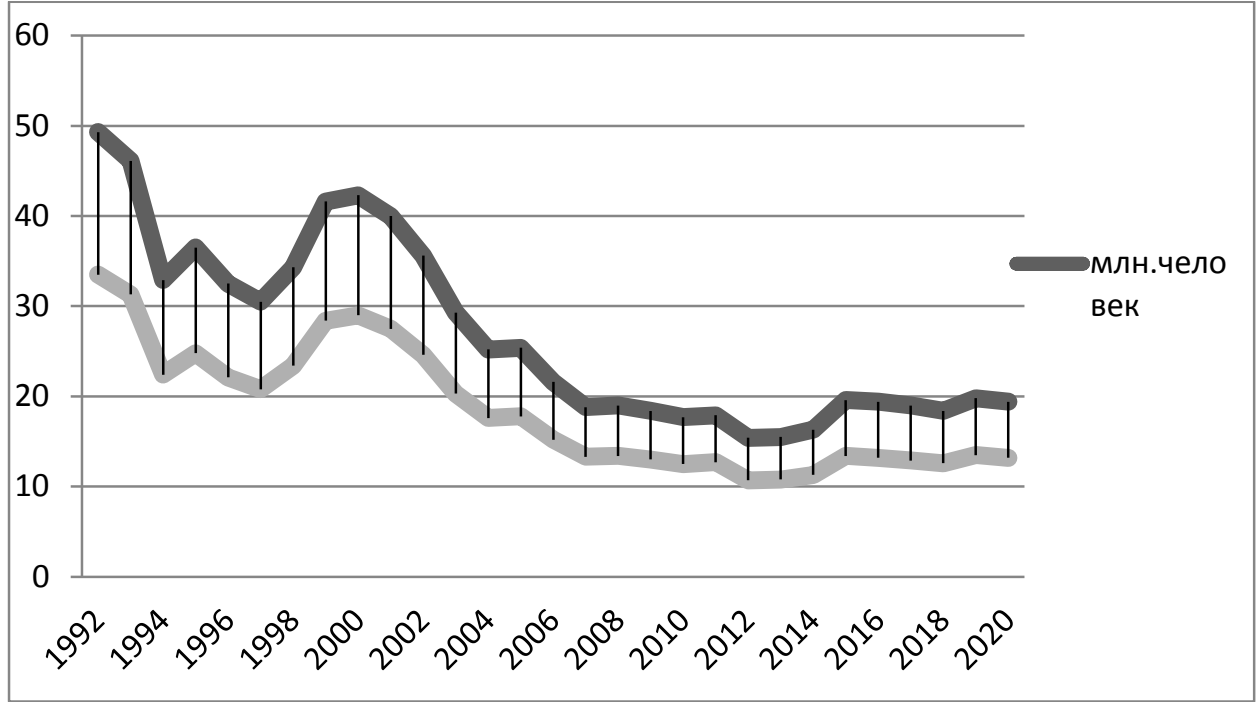

Рис. 2. Динамика уровня бедности населения России (1992-2020 гг.)

Бедность в Российской Федерации растет из года в год. Свою роль в увеличение числа малообеспеченных семей внес и экономический кризис. Увеличение числа малоимущих семей является неоспоримой проблемой для экономики, преодоление которой может затянуться на несколько десятков лет. В 2013 г. доход ниже прожиточного минимума был у 12 млн человек, а по состоянию на 2018 г. таких семей более 19 млн. Состав этих семей разный: с одним или двумя родителями, воспитывающими одного или нескольких детей, многодетные семьи, а также семьи опекунов и подопечных. Основными проблемами таких семей являются материальные трудности, связанные с потерей работы или кормильцев, нарко-, алкозависимостью, асоциальным поведением, необразованностью, вследствие чего члены семьи не способны устроиться на работу с достойной оплатой труда. Но также малоимущие семьи сталкиваются с проблемами ухудшения психологической атмосферы в семье, ведущей к психологическому напряжению, что, в свою очередь, зарождает семейные конфликты, из которых возникают проблемы с воспитанием детей. Дети в таких семьях подвергаются стрессовому состоянию, обусловленному недостатком денежных средств, что является именно той причиной, которая содержит риск развития у ребенка зависти к сверстникам и падения авторитета родителей.

Таким образом, последствия малообеспеченности могут повлечь и влекут за собой асоциальные установки, а социальная поддержка малообеспеченных семей на сегодняшний день становится все более актуальной, но нуждается в доработках и совершенствовании.

Росту численности малоимущего населения способствовало снижение деловой активности в период пандемии и, как следствие, снижение реальных денежных доходов. Вместе с тем в объеме денежных доходов населения за II квартал 2020 г. учтены 359,4 млрд р., которые были выделены Правительством РФ в качестве дополнительных мер социальной поддержки населения в период пандемии. Большая их часть была предназначена семьям с детьми. Это позволило в 
значительной степени смягчить экономические последствия ограничительных мер и минимизировать рост числа жителей страны с доходами ниже прожиточного минимума.

Численность безработных в России в августе 2020 г., по предварительным данным, составила около 4,81 млн человек, что на 47,6\% больше показателя за август 2019 г., в августе 3,6 млн человек были зарегистрированы в качестве безработных, а 3,4 млн человек получали пособие по безработице.

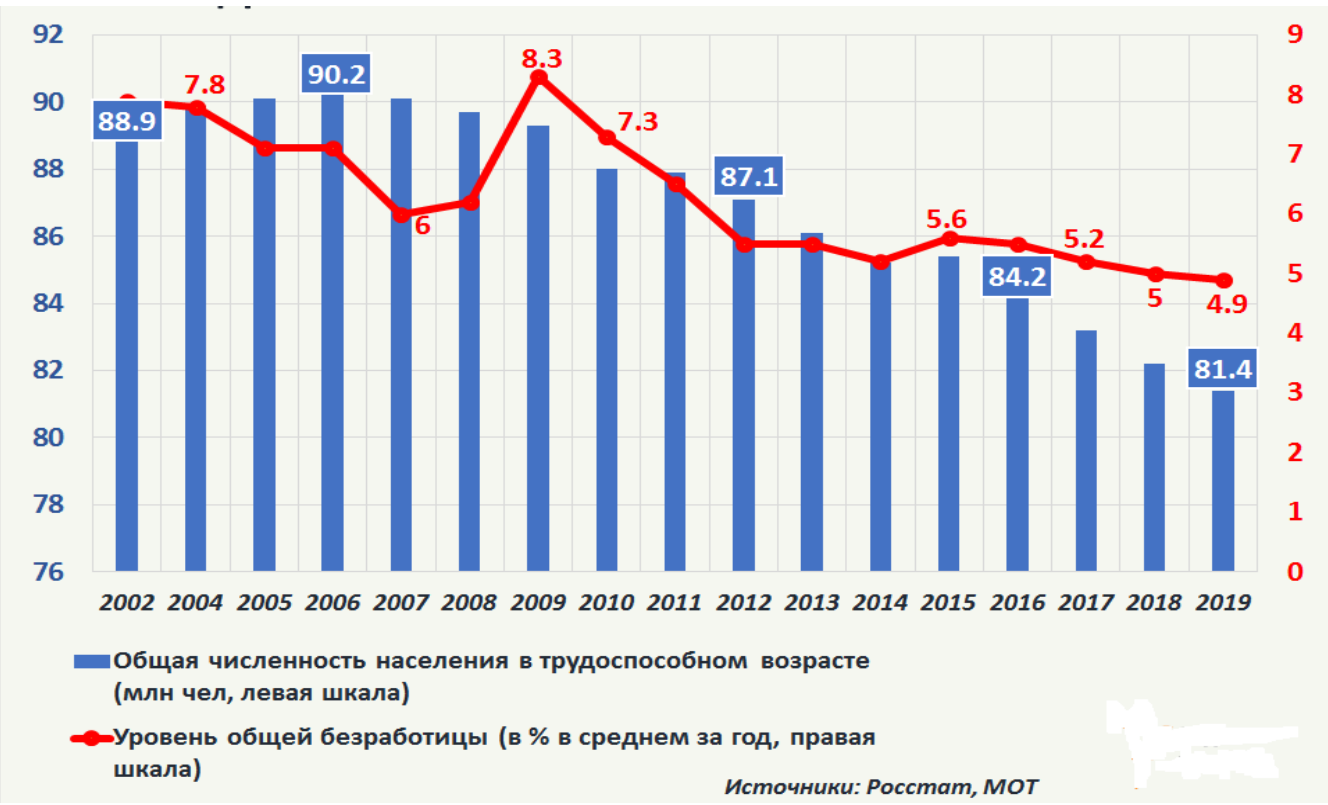

Рис. 3. Динамика трудоспособных и безработных в России

Для измерения бедности Росстат использует концепцию абсолютной бедности, когда доходы населения соотносятся с установленной чертой бедности прожиточным минимумом (во втором квартале 2020 г. - 11468 р.). Размер среднедушевых доходов населения во втором квартале 2020 г. составил 32,85 тыс. р. против 34,5 тыс. р. год назад.

Уровень бедности (численность и доля населения с доходами ниже прожиточного минимума) определяется на основе выборочных обследований бюджетов домохозяйств. Они проводятся каждый квартал и охватывают 48,5 тыс. домохозяйств.

Одновременно последствием карантинных ограничений стало снижение трудовых доходов россиян: работников переводили на неполный рабочий день и отправляли в неоплачиваемые отпуска. По результатам опросов НИУ ВШЭ в мае - июне 2020 г., 23\% респондентов сообщили, что после начала пандемии у них сократилась зарплата, 15\% опрошенных полностью или частично лишились премий и бонусов, 9\% были переведены на неполный рабочий день или неполную рабочую неделю, около $12 \%$ отправлены в вынужденные отпуска. 
Н. В. Кондрашова, А. А. Михайлова. Методы оценки социально-экономического положения малообеспеченных семей

Еще одним индикатором падения доходов населения стало рекордное снижение покупательной способности россиян, она упала до минимума за последние десять лет по 12 из 24 основных продуктов питания (среди них белый и ржаной хлеб, говядина, рыба, рис, яблоки, молоко, сливочное масло, черный чай и др.), оценили в Центре развития ВШЭ.

Во время острой фазы кризиса правительство инициировало антикризисные программы поддержки населения - это прежде всего меры социальной помощи, имеющие ограниченные сроки действия. Российские семьи дважды получили разовые выплаты по 10 тыс. р. на детей до 16 лет, а на детей до трех лет в размеpe 5 тыс. p. в апреле - июне 2020 г., безработные родители вместе с пособием по безработице получали доплаты 3 тыс. р. на ребенка и др.

Антикризисная поддержка действительно поддержала семьи с детьми, но выплаты не позволили полностью компенсировать потерянные доходы и вернуться на докризисный уровень.

Бурятия попала в число регионов с самой большой долей граждан с доходами ниже прожиточного минимума. По данным Росстата, их доля по итогам 2019 г. составила 20,1\%. Есть регионы, где ситуация складывается еще хуже. Наибольшая доля россиян с доходами ниже прожиточного минимума проживает в Тыве $(34,7 \%)$, Ингушетии (30,5\%) и Кабардино-Балкарии (24,2\%). В пятерке антилидеров Республика Алтай $(24,2 \%)$ и Еврейская автономная область $(23,9 \%)$ [7].

Еврейская область в этом смысле возглавляет тройку самых бедных регионов в ДФО, за ней идут Забайкальский край $(21,5 \%)$ и Бурятия (20,1\%) [7].

Меньше граждан с доходами ниже прожиточного минимума в ЯмалоНенецком автономном округе (5,6\%), Санкт-Петербурге (6,6\%), Москве $(6,6 \%)$, Татарстане (6,9\%) и Московской области $(7,3 \%)$ [7].

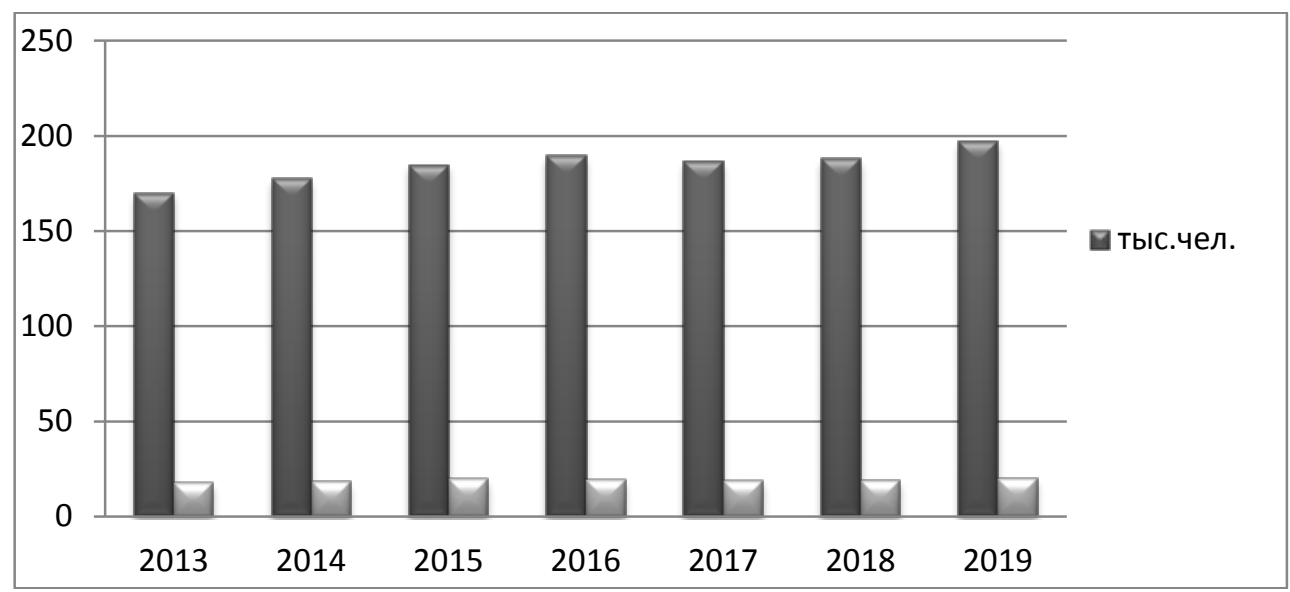

Рис. 4. Динамика уровня бедности населения Республики Бурятия (2013-2019 гг.)

Итак, бедность как социальное явление можно оценить в сравнении с благополучием других. Принято разделять бедность «социальную» и «экономическую». Первая присуща тем категориям населения, которые не участвуют в сфере общественного производства, а вторая характерна для трудоспособной части 
населения, которая не может обеспечить себе достойный уровень дохода. Бедность характеризуется глубиной, устойчивостью, предметностью.

Состояние бедности зависит от ряда факторов, которые можно назвать объективными: экономических, социально-медицинских, демографических, социально-экономических, образовательных и других. Более подробно речь о них пойдет ниже. Однако интересно было бы указать и на другие причины, которые можно назвать абстрактными или субъективными, но значение их зачастую не менее велико:

- личные особенности индивида (лень, глупость, мировоззрение, жизненная позиция и жизненная философия, физические недостатки);

- сторонняя деятельность, направленная на лишение индивида средств или возможности их получать (конкуренты, недруги, соседи и т. д.);

- пороки общественно-экономического устройства (мотивации преуспеть, быть лучше, богаче, занять достойное место и др.);

- случайное совпадение негативных факторов;

- осознанная миссия жизни, не позволяющая жить богато/бедно (в том числе и религиозные убеждения).

Малообеспеченные семьи представляются особым видом бедности, если рассматривать их через призму материальной обеспеченности. Как пишет Н. Щека [8], малообеспеченной считается та семья, доход которой, разделенный на каждого из членов семьи, оказывается ниже прожиточного минимума. Приведем еще одно определение: «Малообеспеченные слои населения - это специфическое состояние материальной обеспеченности людей, когда доходы человека или семьи ниже прожиточного минимума». Рядом исследователей делается особый акцент на то, что малоимущие семьи имеют доход ниже величины прожиточного минимума по не зависящим от них причинам.

Как указывает А. В. Комарова [2], статус «малоимущая семья» зависит от количества человек в семье и уровня их дохода. Такой статус получают неполные, а также молодые многодетные семьи, чей душевой доход ниже прожиточного минимума. Такие семьи не в состоянии предоставить детям возможностей полноценного физического и общекультурного развития, поддерживать и обеспечивать их интересы на должном уровне. Но семью невозможно признать малоимущей в случае, если родители, являясь трудоспособными, злоупотребляют наркотиками или алкоголем.

В особо тяжелом положении находятся безработные семьи, в которых есть дети. Значительная часть малоимущих граждан вовсе не обладает какой-либо профессией либо они становятся безработными ввиду низкой квалификации или невостребованности профессии. Как бы то ни было, безработица, затронувшая хотя бы одного из членов семьи, в большинстве случаев ведет к депрессии, апатии и другим негативным состояниям, вплоть до попыток суицида, снижает уровень жизни и общее моральное состояние семьи.

Согласно данным, представленным коллективом авторов Института социологии РАН, в условиях бедности (в том числе и состоянии нищеты) в России оказался практически каждый пятый житель страны. При этом разрыв между богатыми и бедными достигает в среднем 30 раз, а доминирующим слоем в российском обществе оказались «малообеспеченные» граждане. 
Н. В. Кондрашова, А. А. Михайлова. Методы оценки социально-экономического положения малообеспеченных семей

Согласно классификации, предложенной Всероссийским центром уровня жизни, можно выделить пять групп населения по уровню их доходов. Первая группа (бедные) - душевой доход ниже прожиточного минимума. Специалист по социологии семьи Е. М. Черняк отмечает, что это величина «мифическая», так как не рассчитана ни теоретиками, ни практиками. Вторая группа (малообеспеченные) - душевой доход между прожиточным минимумом и минимальным потребительским бюджетом. Третья группа (обеспеченные) - доход выше минимального потребительского бюджета. Четвертая группа (состоятельные) доход между средним душевым, средним бюджетом и средним рациональным потребительским бюджетом. Пятая группа (богатые) - доходы выше уровня рационального бюджета.

Если отталкиваться от размера прожиточного минимума, то различия между этими группами будут выглядеть следующим образом:

Бедные группы населения - 1 прожиточный минимум

Малообеспеченные группы - 2-2,5 прожиточных минимума.

Средняя группа - 6-7 прожиточных минимумов.

Обеспеченные и богатые - более 10 прожиточных минимумов.

Можно также выделить некоторые социально-демографические факторы, оказывающие влияние на вероятность попадания в малообеспеченные слои. Вопервых, пожилой возраст, во-вторых, здоровье, в-третьих, семейное положение и, как следствие, уровень иждивенческой нагрузки. Что касается половой принадлежности, то здесь отмечается примерно равная доля вероятности попадания в категорию «малообеспеченные», как для мужчин, так и для женщин.

Таким образом, к нуждающимся в помощи гражданам относятся инвалиды I и II групп, престарелые жители (от 80 лет), многодетные семьи, люди пенсионного возраста, многодетные семьи, неполные семьи, семьи с детьми, студенческие семьи, вынужденные переселенцы, бездомные, беженцы, представители асоциальных слоев (алкозависимые, наркозависимые, правонарушители). Среди причин появления малообеспеченных семей, как правило, выделяют следующие: безработица, высокий уровень заболеваемости, смертности, низкий уровень рождаемости, старость, наличие неполных семей, низкий уровень образования населения, высокий уровень преступности и криминальности, асоциальность и социальная изолированность. Большое влияние оказывают маленькая оплата труда, высокие расценки на жилищно-общественное обслуживание, продукты питания и одежд. Не каждой семье доступно и получение элементарных услуг, таких как образование, медицинское обслуживание, отдых и др.

Таким образом, появление малоимущих семей есть результат современной экономической, политической ситуации, сложившейся в стране и оказавшей влияние на ослабленные слои населения, в том числе и семьи. В современных реалиях за чертой бедности часто оказываются не только социально уязвимые категории семей (многодетные, неполные), но и семьи относительно благополучные, которые по каким-либо причинам не смогли адаптироваться к кризисной ситуации и условиям рынка. Большинство бедных семей России - трудоспособные семьи с детьми. Между тем сама бедность неоднородна, и часть бедных семей находится в тяжелом кризисном состоянии и существовании на грани выживания. К таким семьям можно применить понятие «кризисная семья», то есть се- 
мья, находящаяся ниже черты бедности и существующая в условиях физического выживания. В целом же большинство семей находится в состоянии выживания и борьбы за материальное благополучие.

Обобщая вышеизложенные причины роста малообеспеченных семей, приведем классификацию В. И. Курбатовой [3], которая позволяет более структурно представить истоки проблемы. Итак, среди причин попадания семей в группу малообеспеченных выделяем:

1. Экономические причины: прожиточный уровень ниже черты бедности.

2. Асоциальные причины: алкоголизм, наркомания, противоправное поведение, отклоняющееся поведение, невысокий уровень культурного развития

3. Психологические причины: жестокость, агрессивность, грубость, конфликтность, ревность, супружеская неверность, эгоизм, жадность, неуравновешенность.

4. Медицинские причины: хронические заболевания, отклонения.

5. Неполные семьи.

Справедливо было бы отметить, что причины перехода семьи к статусу малоимущей могут быть как объективные, так и субъективные. К первой группе относятся безработица, недостаточная оплата труда, плохое состояние здоровья, ограничивающее трудоспособность, а также уровень иждивенческой нагрузки. К субъективным причинам относятся личные целевые установки, интересы, отношение, уровень личной активности и стремление к исправлению ситуации. Нередко взрослые и трудоспособные члены семьи перекладывают всю полноту ответственности на государство и социальных работников, предпочитая оставаться на иждивенческих позициях и искать внешние причины своего неблагополучия.

Как бы то ни было, но отсутствие средств для полноценной жизни в таких семьях приводит к резкому изменению не только образа жизни, но и психологии членов семьи, появляются асоциальные формы жизнедеятельности, происходят необратимые психологические процессы. На бытовом уровне острая нехватка денежных средств влечет за собой употребление низкокачественной продукции (продукты, медикаменты, услуги и т. д.), а затем и снижение общего интеллектуального, культурного, духовного уровня, физического здоровья членов семьи.

Статус малоимущей семье присваивается муниципальными органами власти, которые подробно анализируют материальное положение семьи и ее доходы. Для определения уровня бедности используются такие подходы, как:

Абсолютный уровень (абсолютная бедность) - домохозяйства и отдельные граждане, у которых нет возможности удовлетворить свои потребности даже на минимальном уровне.

Относительный уровень (относительная бедность) - отдельные граждане и домохозяйства с более низким уровнем материальной обеспеченности, чем все остальные.

Субъективный уровень - граждане, которые считают, что уровень их доходов не обеспечивает им достойной жизни.

Уровень жизни населения определяется исходя из установленного прожиточного минимума. Он представляет собой стоимостную оценку минимального набора продуктов питания, непродовольственных товаров и услуг, необходимых 
Н. В. Кондрашова, А. А. Михайлова. Методы оценки социально-экономического положения малообеспеченных семей

для жизни человека при определенном уровне развития экономики. Расходы на продукты питания, непродовольственные товары и услуги рассчитываются исходя из минимальных размеров их потребления. Устанавливается прожиточный минимум Правительством Российской Федерации на основе представления от Министерства труда и социального развития РФ, Комитета по статистике РФ. Именно от величины прожиточного минимума зависят социальная политика государства, утверждение федеральных социальных программ, определение МРОТ и размера пенсий, субсидий и иных социальных выплат.

Использование прожиточного минимума в качестве критерия для определения бедности не отражает всей глубины проблемы, так как не обеспечивает восстановительного потребления. Для решения проблемы предлагается ввести дополнительные нормативы - «минимальный потребительский бюджет» (МПБ) и «бюджет высокого достатка» (БВД). Первый норматив представляет собой потребительскую корзину, обеспечивающую восстановительный уровень потребления, а второй обеспечивает развивающий уровень потребления, а также платежи и сборы.

Подробно методы измерения уровня бедности были рассмотрены в монографическом труде А. А. Румянцевой «Стратегия преодоления бедности» [5]. Как пишет автор, оценка уровня бедности населения предполагает наличие четкого критерия уровня жизни, при котором человек мог бы считаться бедным, или же наоборот.

В частности, А. А. Румянцева [5] указывает, что для того чтобы обозначить примерную черту бедности, необходимо провести анализ основных потребностей человека, удовлетворение которых и должно быть подкреплено финансовой самостоятельностью семьи. Среди таких базовых потребностей в первую очередь отметим необходимость приобретения различных товаров потребления, как продовольственных, так и непродовольственных. Здесь необходимо определить минимальные затраты на питание при действующих ценах на продукты с учетом степени восполнения энергии посредством питания. Однако провести такой анализ с точки зрения объективной картины довольно сложно, поскольку потребности в восполнении пищевой энергии у разных людей будут различными в зависимости от возраста, массы тела, уровня физической активности. Поэтому такие расчеты могут быть лишь примерными, и они не гарантируют полного и достаточного для человека удовлетворения пищевой потребности. Тем не менее Правительством РФ была рассчитана «потребительская корзина», состав которой напрямую зависит от минимального прожиточного уровня. В ее состав входит набор необходимых товаров, потребляемых ежемесячно одним человеком или всей семьей и которые необходимы ему для поддержания жизненно важных функций. Законодательно потребительская корзина была закреплена Федеральным законом № 227 от 3 декабря 2012 г., вступившим в силу 1 января 2013 г. В настоящем законе говорится о том, что потребительская корзина для основных групп населения должна пересматриваться и устанавливаться не реже чем один раз в пять лет. Потребительская корзина разработана в среднем на душу населения и отдельно для мужчин (16-59 лет) и женщин (16-54 лет), пенсионеров и детей. Корзина состоит из набора различных продуктов питания. На продукто- 
вую часть корзины приходится примерно 1/2 от всей суммы прожиточного минимума, а остальная - на хозяйственные товары и некоторые виды услуг.

Что же касается расчета потребностей в непродовольственных товарах, то ситуация тут еще более сложная и приблизительная, так как единого критерия для расчетов тут не имеется, как, например, в случае с энергетическими затратами.

В качестве отдельных методик можно рассмотреть способы определения абсолютной относительной бедности, что подразумевает анализ в первую очередь физиологических потребностей человека, его нужд в пище, жилье, одежде. При этом потребности более высокого уровня, такие как социально-культурные, практически не учитываются. Итак, если человек не может удовлетворить физиологическую потребность, он находится за чертой бедности.

Относительная же бедность (депривационная концепция) зависит от общепринятого уровня жизни в конкретном обществе в определенное время. Но число лиц, считающихся бедными и реально проживающих за чертой бедности, может быть различным. Кроме того, их численность постоянно меняется, что является существенным недостатком данного подхода.

Среди других методик измерения уровня бедности населения М. В. Игнатюк [5] выделяет следующие:

1. Статистический метод. Согласно данному методу показателями для оценки уровня бедности населения выступают коэффициент бедности (доля бедных семей относительно их общей численности), уровень бедности (процент бедных семей относительно их общей численности) и индекс глубины бедности (степень и доля доходов семьи в сравнении с действующими показателями «черты бедности»).

2. Нормативный метод - базируется на расчете товаров и услуг, необходимых человеку для удовлетворения физиологических и культурных потребностей, и разработке нормативов потребления. О данном методе более подробно нами было сказано ранее.

3. Метод лишений — расчет недопотребления важных товаров и услуг.

4. Стратификационный метод - учитывает и относит к категории бедных тех людей, которые изначально не способны или ограничены в возможностях самообеспечения (старики, дети, люди с ОВ3 и другие).

5. Экономический метод - бедность определяется исходя из ресурсных возможностей государства, направляемых на поддержание материального обеспечения.

6. Эвристический метод - уровень жизни определяется на основе общественного мнения и опроса респондентов.

Рассуждая о критериях определения «бедность», В. М. Сморчкова [6] указывает, что универсального и однозначно подходящего для этого способа не существует. Методов определения помощи нуждающимся гражданам, по ее мнению, можно выделить несколько. Среди них автор подчеркивает:

1) категориальный метод;

2) метод оценки доходов;

3) метод оценки доходов и имущественного положения;

4) балльный метод определения доходов (косвенный метод);

5) метод самоотбора - предполагает создание такого механизма, который бы распространялся на всех граждан, но при этом помощь получали бы только лица, действительно нуждающиеся в государственной поддержке; 
Н. В. Кондрашова, А. А. Михайлова. Методы оценки социально-экономического положения малообеспеченных семей

6) географический метод;

7) метод обеспечения адресности силами местного сообщества.

К сожалению, автор не дает подробных пояснений по каждой указанной методике. Подчеркивает лишь, что оценка доходов потенциального получателя поддержки представляет собой наиболее широко используемую методику.

В качестве примера определения уровня бедности населения приведем логику и содержание фундаментального исследования, проводимого Институтом социологии РАН. Итак, группа ученых РАН для выделения группы малообеспеченных россиян использовала специальный индекс уровня жизни. Исследователи выдвинули гипотезу о том, что уровень жизни определяется не только тем, что имеется у индивида, но и тем, чего он лишен. Для индекса использовались следующие показатели: питание, одежда, досуг, имущественная обеспеченность, наличие недвижимости, жилищные условия, пользование социальными услугами. Особое внимание уделялось анализу показателей дохода в различных социальных слоях в расчете на одного члена семьи. Однако, как указывают авторы исследования, само по себе наличие высокого или низкого дохода не является основанием отнесения семьи к статусу благополучной, малообеспеченной или бедной. В связи с этим был важен анализ сопутствующих показателей - недвижимость, жилищные условия, товары длительного пользования (бытовая техника, мебель и другие предметы обихода) и др. Немаловажное значение имела и оценка самих представителей малообеспеченных слоев своего положения.

Дальнейший ход исследования предполагал рассмотрение экономического поведения малообеспеченных граждан в отношении расходования средств, способов удовлетворения потребностей, анализа конкретных мер, предпринимаемых для улучшения своего положения.

Большое значение имели оценка уровня образования и профессиональная реализация (человеческий капитал), что позволило составить социальнопрофессиональный портрет малообеспеченных слоев населения в России (профессиональный состав, различия в уровне жизни в зависимости от образования и квалификации, месячный доход представителей различных профессий и уровень их жизни).

Специалистами $\mathrm{OOH}$ был разработан подход к определению бедности на основе интегрального показателя - индекса нищеты населения (ИНН), который по-разному исчисляется для развивающихся стран (ИНН-1) и развитых стран (ИНН-2).

Таким образом, для того чтобы судить об уровне обеспеченности семей, необходимо использовать комплексные методики, позволяющие наиболее глубоко проанализировать уровень их жизни, не ограничиваясь денежной и иной материальной составляющей.

Исходя из анализа научных источников по вопросу определения границ бедности можно сделать вывод о том, что понятия «черта бедности» и «бедность» довольно относительные. Их можно рассчитать лишь примерно и приблизительно. Как отметили специалисты РАН, уровень жизни малообеспеченных жителей нашей страны и их экономическое положение наиболее адекватно могут быть описаны термином «относительно стабильное выживание». 
С 2021 г. вводится новый порядок определения прожиточного минимума и минимального размера оплаты труда; предлагается устанавливать на федеральном уровне прожиточный минимум с учетом медианного дохода, а минимальный размер оплаты труда - с учетом медианной заработной платы. При новой методике МРОТ и прожиточный минимум будут расти быстрее, чем при прежних. Минтруд РФ, в свою очередь, ожидает роста этих показателей на уровне выше инфляции. Кроме того, в правительстве рассчитывают, что переход на новую систему поспособствует увеличению пенсий при условии роста медианной зарплаты.

Резюмируя вышеизложенное, отметим, что проблема малообеспеченности для общества довольно актуальная. Это один из наиболее острых социальных вопросов, который требует пристального внимания как со стороны государства, так и со стороны общественности. Данная категория семей считаются экономически и социально не защищенными. Более того, наблюдаются тенденции к увеличению численности малоимущих семей, особенно в свете все расширяющегося разрыва между категориями бедных и богатых.

\section{Литература}

1. Игнатюк М. В. Бедность: дифференциация подходов к определению и измерению // Экономический вестник Ростовского государственного университета. 2008. Т. 6, № 4-2. С. 67-70.

2. Комарова А. В. Актуальные вопросы защиты многодетных и малообеспеченных семей, нуждающихся в социальной защите // Научные исследования социальноэкономического развития общества: материалы междунар. науч.-практ. конф. Саранск, 2017. С. 316-319.

3. Курбатов В. И. Социальная работа: учеб. пособие. Ростов н/Д.: Феникс, 2007. C. 55-297.

4. Михайлова А. А., Кондрашова Н. В. Государственная социальная поддержка малообеспеченных семей в современной России: состояние и проблемы // Социальное самочувствие населения в социокультурном пространстве. Улан-Удэ, 2017. С. 158-161.

5. Румянцева Е. Е. Стратегия преодоления бедности: монография. М.; Берлин: Директ-Медиа, 2015. 444 с.

6. Сморчкова В. М. Адресность государственной социальной поддержки населения: проблемы и перспективы // Проблемы управления. Минск, 2008. С. 251-255.

7. Черкасская Г. В. Борьба с бедностью как фактор развития института социальной защиты // Вестник Ленинградского государственного университета им. А. С. Пушкина. 2010. № 3. C. 77-86.

8. Щека Н. Ю., Микушева И. С. Социальная работа с малообеспеченными семьями: методологический обзор // Образовательная среда вуза: ресурсы, технологии: сб. тр. конф. Благовещенск: Изд-во Амурского гос. ун-та, 2015. С. 303-305.

Статья поступила в редакиию 09.12.2020; одобрена после рецензирования 28.01.2021; принята к публикации 29.01.2021. 


\section{METHODS FOR ASSESSING ECONOMIC AND SOCIAL STATUS OF LOW-INCOME FAMILIES}

Natalia V. Kondrashova

Cand. Sci. (Sociol.), A/Prof.

E-mail: prokusheva0103@mail.ru

Anastasiya A. Mikhailova

Master of Social Work

E-mail: daughter_of_laos_jr@mail.ru

Dorzhi Banzarov Buryat State University

24a Smolina St., Ulan-Ude 670000, Russia

Abstract. The article studies such a category of families as low-income families. We have emphasized the alarming trend of increasing the number of low-income families, and made an attempt to determine the reasons and factors influencing this destructive social process. Low-income families are the result of the current economic and political situation in the country, which influences the weakened strata of the population, in particular families. In realities of the modern world not only socially vulnerable categories of families (multi-child, single-parent households), but also relatively well-to-do families that for whatever reason could not adapt to the crisis and market conditions, often find themselves below the poverty line. Most of poor families in Russia are employable parents with children.

Keywords: poverty; welfare; income; living standards; poverty; minimum wage; market basket; living wage; households with children; level of living. 